\title{
What ARE THE AlTERNATIVE FunCTIONS AND Benefits of Cell Phones for Students?
}

\author{
David Blasco \\ Department of Education，國立中正大學, Jia Yi, Taiwan
}

\begin{abstract}
Taiwanese College students bring their own cell phones in the English classroom and teachers may become overwhelmed with these technology trends. This study aims to provide a realistic perception of the hidden meanings of the use of mobile devices in English class settings and the benefits it can bring to the students. For this purpose, two conventional classes of fourth year license degree in the Department of Travel Management were the respondents. The students' schooling experiences were clarified with a student satisfaction questionnaire, their values highlighted with an interview, and their social interactions explained with observations of the two classes. The results of this study show that, even though they were not used to working collaboratively in small team-work groups, Taiwanese students were highly likely to develop a collaborative learning style that utilizes emails and internet connections matching their learning needs and motivations and optimizing their academic success.
\end{abstract}

\section{KEYWORDS}

Technology, cell phones, emails, collaborative learning, internet connections.

\section{INTRODUCTION}

Two English classes of Taipei College of Maritime Technology (TCMT) located in Tamsuei, Taiwan, learning English in the Department Travel Management were unmotivated to learn English, used to arrive late to class and used their cell phones extensively for other reasons than the course content. Thus, the aim of this paper is to provide a description of the hidden reasons of students' behaviors and ideas which may be strongly related to their cell phone use, and which is too often perceived students' distractive behaviors and inattention in the classroom (Azad, 2013) [1]; Shelton et al, 2009, cited in Azad, 2013 [1]; Stephen and others, 2013[2]). In addition, this study discusses how using mailing with cell phones may help students take more initiative in their learning (Bayless, Clipson \& Wilson,2013) [3]. When students receive a lecture from their teacher, they are highly likely to become uninterested and arrive late to class (Agudo \& Dios, 2014) [4]. Students generally feel less motivated to pay attention to class (Shih, Chuang \& Huang, 2010) [5] and revert to their cell phones to find more interesting occupations.

The paper is organized into the following sections. Section 2 presents the literature review on the subject. Section 3 introduces the methodology used for conducting this study. Section 4presents the results of the survey, followed by a discussion and conclusion in Section 5.

\section{LITERATURE REVIEW}

In an effort to provide concepts of social organization and social relations, Bentley \&others (2011) [6] discussed social order and how it is organized in daily life. They argued that even though people's life appears chaotic to others, it actually happens because of the way it is already put into place. As matter of fact, people's ordinary activities are coordinated purposefully; their social life is organized through social practices that construct their daily lives. In line with Papanikoulao \& Gouli's (2010) [7] concept of group homogeneity, people actually participate in social relations by adapting their behaviors to their social encounters or groups to meet their expectations. Thus, the use of cell phones has been legitimized in the school environment because the majority of

DOI : 10.5121/ijite.2016.5401 
students need them to communicate with their friends and classmates (Altun, 2015) [8]. Moreover, Yesilyurt and colleagues (2014) [9] noted that home computers and internet connections may contribute students' feelings, and that students can communicate with each other utilizing devices.

In his book A complexity theory for public policy, Morcol (2012)[10]discussed Fuchs' definition of self-organization in society as human cooperation, who claimed that "self-organization is a connection of everyday life to ideas such as self-management, resistance, and participatory democracy which is a reproduction of society where cooperation, participation self-determination take place". Fuchs categorized 10 major points regarding self-organization. He asserted that self-organization is based on the active, knowledgeable, transformational societal capacities of human beings:

Table 1. Fuchs' self-organization

\begin{tabular}{|c|c|}
\hline Point 1 & In cooperation the involved actors are mutually dependent. \\
\hline Point 2 & All participating actors benefit from cooperation. \\
\hline Point 3 & Cooperation is based on a shared symbolic system. \\
\hline Point 4 & $\begin{array}{l}\text { Cooperating actors have to a certain extant shared goals or at least a shared } \\
\text { view of certain parts of reality. }\end{array}$ \\
\hline Point 5 & $\begin{array}{l}\text { By cooperating, actors can reach their goals more quickly and more efficiently } \\
\text { than on an individual basis. }\end{array}$ \\
\hline Point 6 & $\begin{array}{l}\text { Cooperation is based on a communication about goals and conventions in order } \\
\text { to reach a common understanding. }\end{array}$ \\
\hline Point 7 & $\begin{array}{l}\text { In cooperation, the actors make concerted use of existing structures in order to } \\
\text { produce new structures. Cooperation is based on sharing the existing and } \\
\text { newly produced structures. }\end{array}$ \\
\hline Point 8 & $\begin{array}{l}\text { Cooperation involves mutual learning and the common production of new } \\
\text { reality. }\end{array}$ \\
\hline Point 9 & Cooperation doesn't mean the absence of conflicts. \\
\hline Point 10 & $\begin{array}{l}\text { In cooperative social relationships there is a high degree of networked, } \\
\text { interconnected activity. The actors depend on each other, mutual } \\
\text { interconnectivity and mutual responsibility emerge. }\end{array}$ \\
\hline
\end{tabular}

As can been seen in Table 1, students may engage in mutual learning by feeling at home and comfortable in their social system (Point 3), when teachers aim to adapt their teaching to their learning needs (Shyamlee \& Phil, 2012) [11]. In agreement with Papanikoulao \& Gouli (2010) [7], people will be able to create and find happiness and social security, participate in decision processes by co-designing their social system. Actually, students may become very dependent on each other when they are working in collaborative groups (Fuchs; cited in Morcol (2012)[10], Point 1) and because they should share goals and views of certain parts of reality (Point 4), they "should work side by side attacking problems, not each other" (Fisher \&Ury, 2012) [12], that way they will be able to benefit from cooperation (Point 2). In addition, as Fuchs (cited in Morcol, 2012) [10] mentioned that cooperation does not mean the absence of conflicts (Point 9), Fisher \& Ury [12] stated that the focus in negotiations must be on interests not positions, that way, a high degree of networked and connectivity can be achieved between all the members of a group (Point 10). In line with Peleckis (2013) [13] and Agudo \& Dios (2014) [4], that emotions help making sense about social relations and that they are best understood in relation to social contexts, students communicate about goals and conventions (Point 6) in order to reach their goals more quickly and efficiently (Carnevale \& Dreu, 2011) students to use.

\section{Methodology}

College students of Taipei College of Maritime Technology studying English in the Department of Travel Management, seemed unmotivated to learn English, used to arrive late to class and used 
their cell phones extensively for other reasons than the course content. This research aims to find out the students' insights of using technology in the classroom, and to bring a discussion on a suitable learning content promoting the students interests in learning English using technology in the classroom, which in turn could encourage their participation. To accomplish this goal, the following research questions will be addressed:

1. How can teachers help students gain more interests in learning English with technology?

2. What are the alternative functions of cellphone for Taiwanese college students?

3. What are the alternative benefits of cell phones for Taiwanese students?

\subsection{Context and Participants}

The site for this study was the Department of Travel Management in Taipei College of Maritime Technology, located in Tamsuei, Taiwan. There were 92 students participating in the current study; one class, 四旅一甲 (=20 males and 29 females), took a "Travel English" course. Another class, 旅二明 (=20 males and 23 females, took the “Tourist English Conversation" course. Both classes were studying two hours of English weekly. They also had weekly a three-hour English class where they studied reading comprehension. As the school rules stipulated that students are to remain in their classroom during class time and are not allowed leaving the premises before the end of class, the interviews and observations were always conducted in the classroom were students were attending their English classes.

\subsection{Procedure}

The survey took place after the spring break of 2015, and lasted for three months. The participants of this study were observed during their attendance from week 1 to week 8.Before taking their mid-term exam, students were requested to answer a questionnaire by circling a value from 1 to 5, which represented the degree of their preferences. Finally, the interviews were conducted with the students on the $10^{\text {th }}$ week, after they all had submitted the filled questionnaire to the researcher.

\subsection{Research design}

As students were usually arriving late to class, the researcher of this study tried to understand the causes of their lack of motivation, and decided to conduct his study as shown in Figure 1.

Travel and Tourist conversation courses from February 2015 to June 2015.

Observations of the students.

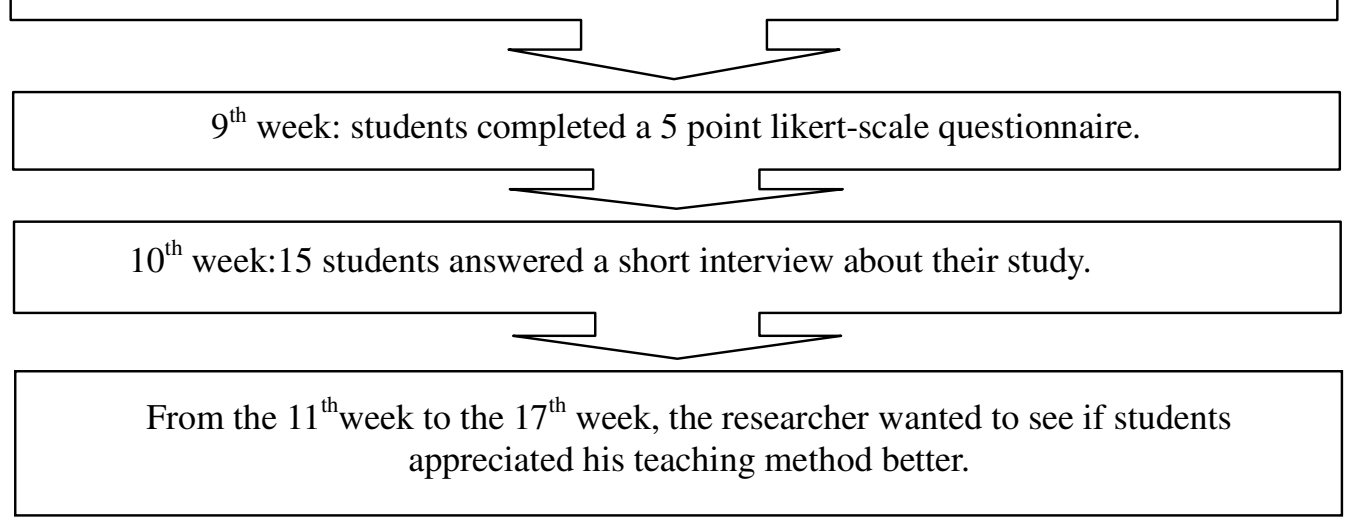

Figure 1.Design of the study 


\subsection{Data analysis}

The observations of the two classes were made every week during class and field notes were written out directly after. These field notes would then become simple memos after reflection (Strauss \& Corbin, 2015) [21].The research also took notes of important points cited by Guest\& others (2013) [22] on the logistics of observations, which include an overview of how to be an effective participant observer.

After their mid-term exam, students were requested to answer a questionnaire by circling their favorite answers. Arshad, Ramani \& Kashif (2014) [23] provided useful information on how to create a self-made questionnaire; besides, Fanni (2014) [24] Computer Self-Efficacy Scale (CSES) was also used; the Likert-scale items ranged from "1" (Strongly Disagree) to "5" (Strongly Agree). A higher score on an item indicated a greater degree of confidence in that element of the basic skill set assessed by the scale.

The interviews were guided by Guest\& others (2013) [22] logistics of interviewing, which include the responsibility of the interviewer to prepare for the interview, to interview the participants thoroughly, and to document the interview. The interview used open-ended questions, which were created from the simple memos of the observations. In addition, Strauss \& Corbin's (2015) [21] provided more detailed information on taking backup notes, expanding notes as soon as possible after the interview, and making an analysis of interview with memos. Moreover, Strauss \& Corbin's Axial coding was useful in creating in categories and concepts to better interpret the interviewees' comments.

\subsection{Data analysis of observations}

The researcher employed field notes to obtain qualitative data. The data was categorized into two categories including the concept of cell phone use and the concept of passive activities of students, according to Strauss \&Corbin's (2015) [21] Axial Coding principles.

\subsection{Data analysis of questionnaires}

Regarding the questionnaire, the researcher used a 5 point-likert scale to gather students' responses. The researcher examined each response provided by the participants in order to minimize invalid responses and missing values. Then, the Cronbach' salpha was employed to test the reliability of the variables. The Cronbach' salpha value of confidence was 0.886 . As the alpha value is usually greater than 0.7 for well-established measures (Yau \& Chen, 2013) [25], the researcher considered that the results were consistent and reliable because the alpha value in this survey was greater than 0.7 .

\subsection{Data analysis of interviews}

Finally, the researcher examined each response of the 16 interviewees and categorized those according to Strauss \& Corbin's (2015) [21] Axial Coding principles.

\section{RESULTS}

\subsection{Results of the observations}

The observations were conducted at the Department of Travel Management in Taipei College of Maritime Technology, located in Tamsuei, Taiwan. The samples were taken from 92 students participating in the current study. One class, 四旅一甲 (=20 males and 29 females), took a “Travel English" course. Another class, 旅二明 (=20 males and 23 females, took the “Tourist English Conversation" course. The observations took place from the first day of class and field notes were written until week 8 of the same semester. Axial Coding was used to categorize the data written during field notes. 
According to the data gathered from the researcher's observations, students did not appear to be enthusiastic with their English learning. The students' passive activities did not allow for valuable learning to take place. As can be seen in Table 2, the students' low level of engagement in class prevented them from communicating with each other and with the teacher.

Table 2. Observations of English classes in Taipei College of Maritime Technology

\begin{tabular}{|c|c|}
\hline Cell phone use & Passive activities of students \\
\hline $\begin{array}{ll}\text { - } & \text { Play online games } \\
\text { - } & \text { Online shopping } \\
\text { - } & \text { Listen to Chinese music } \\
\text { - } & \text { With earpieces } \\
\text { - } & \text { with earpieces } \\
\text { Watch foreign movies } \\
\text { with Chinese subtitles } \\
\text { Individual use of cell } \\
\text { phones }\end{array}$ & $\begin{array}{ll}\text { - } & \text { Open reluctance to study English } \\
\text { - } & \text { Take a sudden leave to smoke outside } \\
\text { - } & \text { Show off tattoos/other particularities } \\
\text { - } & \text { Eat breakfast \& lunch/ brings drinks to share } \\
\text { - } & \text { Never clean up the trash littered in class } \\
\text { - } & \text { Students come empty handed to class and tests } \\
\text { - } & \text { Prepare for other tests, ignore the lesson. } \\
\text { - } & \text { Arrive } 10 \text { minutes before end of class for next class } \\
\text { - } & \text { Partners show affection } \\
\text { - } & \text { Students sleeping in the classroom -boredom } \\
\text { - } & \text { Students bring in their dogs } \\
\text { - } & \text { Chat loudly and make up for hours } \\
\text { - } & \text { Students sign roll call sheets for others } \\
\text { - } & \text { Students may write test papers for others } \\
\text { - } & \text { Written assignments are ignored, forgotten }\end{array}$ \\
\hline
\end{tabular}

According to the concept of cell phone use, students seemed not to be used to work collaboratively in the classroom as they all used their cell phones individually in order to fulfill their own interests. When asked informally with few students at the beginning of class about their interests and hobbies, they revealed that they were quite curious about foreign cultures and learnt it by themselves through various means. For example, girls enjoyed surfing the net for fashionable clothes and listen to foreign songs, while most of the boys preferred watching American movies on their cell phones and listen to Chinese songs. The researcher was also curious to understand the reason for their reluctance to learn English. When some female students where asked this question, they reported that they felt too anxious about the quizzes in their next English class and felt too tired to learn more. Thus there is little wonder that students would behave in an uncooperative manner and being careless about their class cleanliness.

\subsection{Results of the questionnaire}

The questionnaire used a 5point-likert scale to measure the degree of interactions of the students and their college. After the questionnaire shown a level of confidence with a Cronbach' salpha value of 0.886 , it was administered on the $9^{\text {th }}$ week, the same day as the mid-term examination. Out of 92 students enrolled in both classes, only 57 participants responded to the questionnaires the following week after their mid-term test paper was completed. In order to complete the questionnaire, students had to circle the highest value which represented their highest preference. As can be seen in Table 3, have to learn to be self-dependent during the four years of their study.

The first item, convenience of transportation to school, included the items "I come by MRT \& bus, I ride my motorcycle, I come by car, I come by walking, I live in campus". From Table 3, it can be seen that more than $70 \%$ of the students show a high degree of satisfaction, and most of the students are happy to meet their friends when they arrive to school. Nevertheless, TCMT does not provide any transportation service to its students, who have to spend a large amount of money on their tight budget to come to school, but fortunately, a great majority is happy with the quality 
of transportation that is available to them.

The second item, the interactions and communications with the school administration, included the items "financial aid services, academic advice, course selection, course availability, academic level of courses, career counseling". From Table 3 above, it can be seen that only $39 \%$ have reported to being satisfied with the services offered by their school administration. Because students have to pay their tuition fees and receive a small amount of scholarship every semester, they feel that their school is not very efficient in helping them sorting out financial difficulties and giving them essential information on the best possibilities to study more efficiently in order to graduate in due time.

Table 3. Results of the questionnaire

\begin{tabular}{|l|c|c|c|c|c|}
\hline \multicolumn{1}{|c|}{$\begin{array}{c}\text { Questions } \\
\text { I am satisfied with... }\end{array}$} & $\begin{array}{c}\text { Strongly } \\
\text { agree }\end{array}$ & Agree & neutral & disagree & $\begin{array}{c}\text { Strongly } \\
\text { disagree }\end{array}$ \\
\hline $\begin{array}{l}\text { the convenience of the } \\
\text { transportation to school }\end{array}$ & $26 \%$ & $45 \%$ & $19 \%$ & $0 \%$ & $8 \%$ \\
\hline $\begin{array}{l}\text { The interactions and } \\
\text { communications from the school } \\
\text { administration }\end{array}$ & $17 \%$ & $22 \%$ & $45 \%$ & $10 \%$ & $3 \%$ \\
\hline $\begin{array}{l}\text { The interactions and } \\
\text { communications from my } \\
\text { Department daily services }\end{array}$ & $14 \%$ & $15 \%$ & $54 \%$ & $14 \%$ & $1 \%$ \\
\hline $\begin{array}{l}\text { I am satisfied with the school } \\
\text { facilities }\end{array}$ & $8 \%$ & $61 \%$ & $17 \%$ & $12 \%$ & $0 \%$ \\
\hline $\begin{array}{l}\text { I am satisfied with the } \\
\text { extra-curricular activities. }\end{array}$ & & $15 \%$ & $12 \%$ & $3 \%$ \\
\hline
\end{tabular}

The third item, the interactions and communications from my Department daily services, included the items "I can choose the course I really want, the classes are too large, my professors are good teachers, I have the opportunity to develop appropriate management skills". From Table 3 above, it can be seen that $59 \%$ of the students show a neutral degree of satisfaction.As the researcher sometimes asked students informally about their experience of study in their school, some students responded that they did not mind that classes were large, and they felt that teachers were nice and knowledgeable to teach them appropriate management skills which would be useful for their future career. By contrast, they would also like to be able to find course that were more engaging and not just attend lectures all day, even though teachers used social media and PowerPoint to teach. Besides providing lectures, they felt that teachers are out of reach outside the classroom and were receiving little advice from them.

The fourth item, I am satisfied with the school facilities, included the items "campus, classrooms, library, dormitory, food services, arts, sports, parking and medical". As can be seen in Table $3,54 \%$ of the students also showed a neutral degree of satisfaction because they did not see anything special with the school facilities. As there searchers one times chatted with students during breaks, the researcher noticed that they loved sharing their ideas about their hobbies and favorite sports. Most of the boys responded that they loved playing basketball the most with their friends on the school campus and that they often met after classes were over. Nevertheless, 29\% of the students seemed to enjoy taking advantage of the library where they could find their favorite books, while $15 \%$ of the students did not seem to be interested either because they did not have many friends or used to go back home directly after classes were over.

The firth item, I am satisfied with extra-curricular activities, included the items "community services, play sports, spiritual activities, performing arts, recreation and wellness, going to cram-school, meet new friends". In sharp contrast with item four, I am satisfied with the school facilities, it can be seen that nearly $70 \%$ of the students show a high degree of satisfaction 
regarding the extra-curricular activities. While most of the students want to have opportunities to play basketball, other students valued recreational activities to meet new friends. It seems that strengthening relationships with classmates and building new relationships with new playmates is essential to their school life experience. As could be seen in previous items, TCMT students feel that they do not receive much advice from their school administration; they can't ask questions to their teachers outside of class when needed, and have to rely on themselves until they can graduate four years later.

\subsection{Results of the interviews}

The interview was administered on the $10^{\text {th }}$ week, after the participants finished their mid-term examination and filled in their questionnaires. In total, 15 students $(\mathrm{N}=7$ males and 8 females $)$ were randomly selected and were willing to participate to the interview process after they completed their mid-term exam and responding to the questionnaire. Table4presents the results of the interviews.

Table 4. Results of the interviews

\begin{tabular}{|l|c|c|c|c|c|}
\hline \multicolumn{1}{|c|}{ Questions } & $\begin{array}{c}\text { Strongly } \\
\text { agree }\end{array}$ & Agree & neutral & disagree & $\begin{array}{c}\text { Strongly } \\
\text { disagree }\end{array}$ \\
\hline $\begin{array}{l}\text { Is the teachers' use of social } \\
\text { media useful for your study? }\end{array}$ & $33 \%$ & $66 \%$ & $1 \%$ & $0 \%$ & $0 \%$ \\
\hline $\begin{array}{l}\text { Do you feel teachers are helpful } \\
\text { in class? }\end{array}$ & $33 \%$ & $46 \%$ & $21 \%$ & $0 \%$ & $0 \%$ \\
\hline $\begin{array}{l}\text { Do you have the chance to } \\
\text { speak in class? }\end{array}$ & $6 \%$ & $60 \%$ & $22 \%$ & $6 \%$ & $6 \%$ \\
\hline $\begin{array}{l}\text { Do you receive help for } \\
\text { completing your homework? }\end{array}$ & $0 \%$ & $66 \%$ & $0 \%$ & $33 \%$ & $1 \%$ \\
\hline Do you enjoy self-studying? & $0 \%$ & $26 \%$ & $1 \%$ & $66 \%$ & $7 \%$ \\
\hline
\end{tabular}

In the first item, Is the teachers' use of social media useful for your study? , the raw data was developed under the concept of "the use of social media". All the students responded that their teachers make use the PowerPoint and YouTube to deliver their lectures, and that they are useful to understand the key points of the lessons. Instead of writing lengthy notes, students reported that they take pictures of the most interesting slides and save them in order to review for tests if needed. Nevertheless, these students also reported that when their teachers use it for long period of times to deliver lectures, it becomes uninteresting(See Questionnaire, Item 3).

In the second item, Do you feel that teachers are helpful to help you learn in class? ,the raw data was developed under the concept of "teachers' help in class". Nearly $80 \%$ of the students feel that their teachers are helpful in their study. While one student reported that he thought that "teachers were friendly and knowledgeable", another said that "teachers are happy to answer their questions, and that their answers seem to be relevant". These two previous statements show that teachers generally do not ask questions to their students. In addition, students reported that teachers are difficult to reach out outside of class and seem to be keeping a distance based on a teacher-student positioning, which prevents them from understanding their students' learning needs (See Questionnaire, Item 2).

In the third item, Do have the chance to speak in class?, the raw data was developed under the concept of "taking chances to speak up in class". When asked if they had the chance to speak up in class, $66 \%$ of the students reported that they would ask questions to their teachers when they believe some points are important. By contrast, 33\% of them thought that do not provide enough chances to speak out because they are more focused on delivering their lectures than allowing being interrupted. When I informally asked a student about the reasons why she would have more 
chances to speak English, she answered that she would like to practice some role-plays in class with other classmates, that way she could have a more realistic use of the language she's learning. Thus, even students would like to find more engaging courses (See Questionnaire, Item 3) teachers hers usually do not take advantage of the school facilities to provide their students with chances to speak a foreign language See Questionnaire, item 4). Instead of asking questions about students' understanding during their lectures, they prefer administrating quizzes to check their students' attention and understanding.

In the fourth item, Do you receive help for completing your homework?, the raw data was developed under the concept of "helping students with homework". Results show that $34 \%$ of the students do not go to cram-school to practice their lessons. They also reported that they cannot receive help from their parents who are too busy for their job occupation, thus give their child the sole responsibility for their study. This finding is in agreement with all the questionnaire answers that when College students study at TCMT, they receive little support and tend to rely on their classmates and friends for school and social assistance. When asked if their parents ever come to school to discuss their child's study, interviewees answered that they would simply make a phone call to the school when necessary. By contrast, results also show that $66 \%$ of the students reported being busy exchanging information on course content and homework. Most of the students said "we use our cell phones to ask questions to our friends about what the teacher said", which means that they value an exchange of information taking place not only on face-to-face interactions, but also with online and internet connections. Because students regularly receive short quizzes about their comprehension on lesson content, they need to ask their classmates some information about homework to be done or on course contents that they did not understand. It is highly likely that students usually work at building friendly relationships to receive support from their classmates in order to maximize their chances of academic success.

Finally, the fifth item, Do you enjoy self-studying?, the raw data was developed under the concept of "experiencing self-study". As can be seen in Table 4, nearly $75 \%$ of the students confirmed that students do not enjoy studying by themselves and avoided going to the library. In a different light, more than $25 \%$ of the students went to the school library to spend their free time after class to read travel magazines they liked, learned languages they found more interesting such as learning Japanese, reading newspapers and surfing the internet. In agreement with the fifth item of the questionnaire, I am satisfied with extra-curricular activities, these students take advantage of their curiosity for recreational activities. It is highly likely that if English teachers could use campus spaces such as art center or sport areas, students could be given more chances to engage learning activities. Thus it is understandable that even though the school library is equipped with computers programmed with free online TOEIC and TOEFL practice tests, none of the students mentioned that they had ever used it. In agreement with the fourth item of the interview "Do you receive help for completing your homework?"students would be very likely to prefer sharing information on English learning while being connected online with their classmates.

\section{DisCuSSION AND CONCLUSIONS}

This study aimed to provide a realistic perception of the hidden meanings of the use of mobile phones in Taiwanese College English class settings. The goal of this study was also to point out the alternative functions and benefits cell phones can bring to the students in order to promote collaborative learning that utilizes emails and internet connections matching their learning needs and motivations and optimizing their academic success. Three research questions were posed to do just this.

Finding the answer to the first question "How can teachers help students gain more interests in learning English with technology?" was an arduous task because the English class appeared to be chaotic from the first day of the semester due to the students" "passive activities" during class 
(Morcol, 2012) [10]; Azad, 2013, p.458 [1]; Shelton et al, 2009, cited in Azad, 2013, pp.457-458; Stephen and others, 2013, p.120 [2]).When the researcher started his class students were often late, and he wondered if that situation was due to the students' unwillingness to come to school to study or only to their commuting (See Questionnaire, Item 1). But according to Morcol (2012) [10] and Papanikoulao \& Gouli (2010) [7], Taiwanese students in TCMT found happiness and social security within their groups, participate in decision processes by co-designing their social system that was their own and that outsiders could hardly understand. Questionnaire and interview results showed that students in general build and strengthen their relationships outside of class and felt that they were not given enough support and advice from the school administration, their department and their teachers regarding their after class assignments and study opportunities (See Questionnaire, Items $2 \& 3$ ).

Even though the answers to the interview question "Do you feel that teachers are helpful to help you learn in class? show that students may ask occasional questions, students usually move away from lectures and start showing signs of "passive activities" such as arriving late for class (Agudo \& Dios, 2014) [4]because teachers generally come to class to do their jobs and have not realized that it was necessary to develop deeper connections in the teacher-student relationship. Students generally feel less motivated to pay attention (Shih, Chuang \& Huang, 2010) [5] and revert to their cell phones to find more interesting occupations (See Questionnaire, Item 3).As TCMT students seem satisfied with their commuting to school, results of this study confirmed that students' late arrival to class is due to the teachers' lectures that have become uninteresting to them.

In order to help students take more initiatives during the English class, the teacher has to find ways of a more liberal and democratic teaching approaches to adapt his teaching to his students' learning needs (Shyamlee \& Phil, 2012) [11]. In order to do that, the teacher's high self-concern and low concern for the students had to be switched to a lower concern for the teacher's self and higher concern for the students (Peleckis,2013[13]; Fisher \& Ury, 2012 [12]). As the researcher learnt that his students did not particularly enjoy their teachers' lectures, he decided to stop lecturing them formally and meet them on a one-on-one level because he also depended on their agreement to collaborate with him in their learning process (Fuchs, cited in Morcol, 2012) [10], Point 1; Miangah \& Nezarat, 2012 [15]). By meeting the students on a one-on-one level, the researcher could not only answer their questions about difficulties they had in translating sentence drills in Chinese or in English, but also focus on the students' interests to build a high degree of networked and connectivity (Fisher \& Ury, 2012) [12] by putting himself in their shoes and guide them in their study so not to let fall into their "passive activities".

When the students were practicing translations of their sentence drills individually, they used their cell phones as an electronic dictionary and occasionally looked for feedback from their classmates. As they were slowly building more confidence in this activity, the researcher improved his teaching method by asking his students to write three sentence patterns on their cell phones or computers and to send them to him on his Gmail address ( $\mathrm{Ou}, 2015)$ [16]; Al-Mohammadi \& Derbel (2014) [17]; Ogunduyile, A., O. (2013) [18]; Tai \& Ting (2011) [19]), which was thought to be extremely helpful to building new friendships and gain extra help either for students or the researcher ( Miangah \& Nezarat, 2012 ) [15]. Once that some students had agreed to try this new learning approach by sending their translated sentences to the teacher's Gmail account, the teacher would check them, make necessary corrections and send them back to the students.

Regarding the second research question "What are the alternative functions of cell phones for Taiwanese students?, students can bypass simple use of electronic dictionary to make their use of cell phones more valuable. Students were grouped in small groups composed of 2 or 3 students and were asked to finish an activity for their homework when it was not possible to complete it in 
class. These activities were included in their textbooks and consisted of asking each other questions and answering them. Once the students had finalized the answers from their questions, they had to forward them to their teacher' Gmail account, who corrected them and forwarded them back to the students after necessary corrections were made. These small collaborative work-groups matched the students' values to "ask questions and information to classmates" (See Interview, Item 4).The Gmail account also provided the students with the possibility to store their question and answers in a "data bank" where they would choose their favorite sentence to create a basic role-play. This role-play included questions and answers, giving them a challenge of face-to-face interactions in class practice. The use of a webmail and social media such as Facebook or Twitter could also be implemented in TCMT students' classes because, according to Yesilyurt and colleagues (2014) [9] and Altun (2015) [8], home computers and internet connections may contribute students' feelings, and students can communicate with each other utilizing devices in order to reach their goals more quickly and efficiently (Carnevale \& Dreu, 2011) [14]. Thus, social media could help all the students sharing more of their experiences and ideas from their initial question and answer activities and develop their topics of conversations. In turn, these sharing of ideas could be saved in a databank used to create more elaborated role-plays to present in front of their class. Thus, the alternative functions of cell phones are the possibility of translating sentence drills, not only words, and to save them in a "databank" in an internet account. Second, students can look up their data anytime to build their own sets of sentences. Finally, small groups of team-work combine themes of questions \& answers and for developing role-plays.

In a logical sequence, the third research question "What are the alternative benefits of cell phones for Taiwanese students?"discusses some advantages the use of cellphones, combined with small team-work groups, can bring to the students. The researcher noted that when his students used their cell phones by bypassing their individual use of basic electronic dictionary, they develop lists of sentences pattern on their own instead of being fed by uninteresting lectures. Second, instead of remaining quiet for long period of times in the classroom, students started to elaborate discussions from their "data bank" saved in their social media accounts. Third, instead of constantly working individually, students gradually spent more time on developing role-plays. Finally, instead of arriving late for class, several students took more initiatives to prepare role-plays and perform English conversations with their groups.In conclusion, the alternative functions and benefits of cell phones for students not only help students sharing information about class content, but also taking more initiative in increasing their knowledge base and learning to work collaboratively in small groups, which will increase the learning time spent in class (Bayless, Clipson \& Wilson,2013) [3].

There are some limitations to this study. First, the number of participants answering the questionnaire samples was small $(\mathrm{N}=57)$. More participants could have rendered the insights of the students who responded more valid. Second, students in TCMT had a high level of absence rate which may have affected some students' study. Third, the web mailor other social media has not yet been implemented by the teacher in his own classroom. It is suggested that more social media tools such as Facebook and Twitter be implemented in the classroom to spark students' curiosity and interest. More importantly, Taiwan is well known for its "technology and innovation driven" industrial development policies. The rise of digital assistants in Taiwan is leading to a new kind of optimization, and Taiwanese college students are highly likely to use them in the classroom. While digital assistants use traditional search engines, the key optimizing of the new format of digital assistant is to make sure that information is accessible to these assistants, rather than trying to funnel people to a specific site. Thus, it is recommended that further research investigates if a flexible use (Blasco, 2016) [20] of PDAs in Taiwanese classrooms allows students to access to more information in their English learning, and also verify if its use can improve students'academic performance. 
International Journal on Integrating Technology in Education (IJITE) Vol.5, No.4, December 2016

\section{ACKNOWLEDGEMENTS}

I would like to express my sincerest thanks and appreciation to the students of Taipei College of Maritime Technology for their patience and willingness to participate in this study, without whom I could nothave found the most adapted teaching method that would have suited their learning needs.

\section{REFERENCES}

[1] Azad, A. A. (2013). Etiquette, E-etiquette and cell phone use in the classroom. Issues for Information systems, 14(2), 452-462.

[2] Stephen, F., Bayless M.L., Clipson W.T., Wilson S.A. (2013). Faculty perceptions and policies of students' use of personal Technology in the classroom. Business communication and Legal Studies, 32, 118-136.

[3] Bayless, M.I., Clipson, T.W., Wilson, S.A. (2013). Faculty Perception and Policies of Students' use of personal Technology in the classroom.

[4] Agudo, M. \& Dios, J.D. (2014). English as a foreign language teacher education: Current perspectives and challenges. Amsterdam: Rodopi, 364 pages.

[5] Shih, J.L., Chuang, C.W., Hwang, G.J. (2010). An inquiry-based learning approach to Enhancing Social science learning effectiveness. Educational Technology \& Society, 13(4), 50-62.

[6] Bentley, A., Earls, M., O’Brian, M., J. (2011).I will have what she's having. Mapping social Behavior. London, England: MIT Press.

[7] Papanikolao, K., Gouli, E. (2010). Collaboration as an opportunity for individual development. International Conference on Intelligent Networking and Collaborative Systems. Thessaloniki, Greece, pp.24-26.

[8] Altun, M. (2015). The integration of technology into foreign language teaching. International Journal on New Trends in Education and their Implications, 6(1), 22-27.

[9] Yesilyurt, M. E., Basturk, R., Yesilyurt, F., Kara, I. (2014). The Effect of Technological Devices on Student's Academic Success: Evidence from Denizli. Journal of Internet Applications and Management, 5(1), 39-47.

[10] Morcol, G. (2012).A complexity theory for public policy. Routledge: NewYork.

[11] Shyamlee, D., \& Phil, D. (2012). Use of technology in English language teaching and learning: An analysis.2012 International conference on language, Medias \& Cultures. IACSIT Press, Singapore.

[12] Fisher, R. \&Ury, W. (2012). Getting to yes. Negotiating an agreement without giving in. Random House Business Book ( $3 \mathrm{r}$ ed.): London.

[13] Peleckis, K.(2013). International business negotiations: Culture, dimension, context. International Journal of Business, Humanities and Technology, 3(7), 91-99.

[14] Carnevale, P.J, \& Dreu, C. K. W. D. (2011). Methods of Negotiation research: International negotiation. Leiden Netherlands:MartinusNijhoff.

[15] Miangah, M.T., Nezarat, A. (2012). Mobile-Assisted Language learning. International Journal of Distributed and Parallel Systems, 3 (1), 309-319. 
International Journal on Integrating Technology in Education (IJITE) Vol.5, No.4, December 2016

[16] Ou, F.C. (2015). Using mobile devices to improve primary educational outcomes: an analysis in Primary education. International Journal of Learning, Teaching and Educational Research, 12(3), 28-45.

[17] Al-Mohammadi, S., \& Derbel, E.(2014). The effects of Embedding information Technologies within ELT on EFL learners ' motivation and interests. International Journal of Applied Linguistics \& English Literature, 3(1), 181-185.

[18] Ogunduyile, A., O. (2013). Towards the integration of mobile phones in the teaching of English language in secondary schools in Akure, Nigeria. Theory and Practice Language Studies 3(7), 1149-1153.

[19] Tai, Y., Ting, Y-L. (2011). Adoption of mobile technology for language learning: teacher attitudes and challenges. Jaltcall journal 7(1), pp.3-18.

[20] Blasco, D. (2016). Students' attitudes toward integrating mobile technology into translation activities. International Journal on Integrating technology in Education, 5(1), 1-11.

[21] Strauss, A., Corbin, J. (2015). Basics of qualitative research: Grounded theory procedures and techniques $\left(4^{\text {th }}\right.$ ed.). Thousand Oaks CA: SAGE Publications.

[22] Guest, G., S., Namey, E., E., \& Mitchell, M.L. (2013). Collecting qualitative data: A field manual for applied research. Thousand Oak, CA: SAGE.

[23] Arshad, M., Ramani, H. S., Kashif, N. U. (2014). Developing a reliable and valid questionnaire to measure students' satisfaction level on their courses experiences at University level in Pakistan. Pensee Journal, 77,3, p. 393-405. Retrieved form http://www.academia.edu/6765032/Reliability_and_validity_of_survey_questionnaire

[24] Fanni, F. (2014). Confidence in technology use: The development and validation of a technological, edagogical, and content self-efficacy scale for teachers. Retrieved from http://doc.rero.ch/record/210297/files/2014COM007.pdf

[25] Yau, H.,K., \& Cheng, A., L.,F. (2013). Engineering students' grade level differences of Satisfaction in using technology for learning. International Journal of Modern Education Forum, 2(3), 66-70.

\section{Author}

I grew up and studied in the South of France and earned a bachelor degree in Marketing. While studying in France, I developed an early interest in international relations while learning English. I lived and worked in the United Kingdom for three years, and I moved to Taipei with my wife in 1999. Having a background in cultures of these countries, and being an independent user of the Chinese language as well, I have developed a curious mind regarding the teaching of English for Business Purposes. Due to this, while as I was working as an English and French and teacher in Taipei, I studied in both National Taiwan University of Science and Technology in the department of

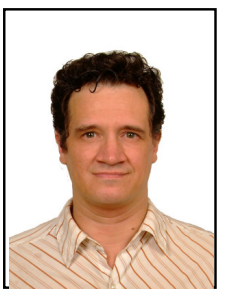
Applied Foreign Languages as well as National Taipei University, Global MBA program.

As a lifelong learning project, I decided to pursue a $\mathrm{PhD}$ in education in 2012, at Chung Cheng University, located in Jia Yi. The purpose of my study is to earn a doctoral degree to support the teaching my business skills gained from NTU Global MBA program, which are relevant to the teaching of English for Business purpose to University students.

My study at the Global MBA program combined with the teaching of foreign languages provided me with the opportunity to join Taipei college of Maritime technology, located in Tamsuei, and to gain my first experience at teaching English for commercial and leisure purposes. As I taught English for more than three years, I came to understand Chinese learners better and apply my learning in Applied Foreign Languages to develop teaching materials that were adapted to their learning styles. 